\title{
The Effect of Various Sterilization Techniques to the Growth of Fingerroot Explants (Boesenbergia Pandurata Roxb)
}

\author{
Epin Pinasti ${ }^{1}$, Liberty Chaidir ${ }^{2}$, Dikayani $^{3}$, Adjat Sudrajat ${ }^{4}$ \\ \{pinastifebruari@gmail.com ${ }^{1}$, libertychaidir@uinsgd.ac.id ${ }^{2}$, dikayani@fst.uinsgd.ac.id ${ }^{3}$, \\ adjatsudrajat@gmail.com ${ }^{4}$, \\ Faculty of Science and Technology, UIN Sunan Gunung Djati Bandung ${ }^{1}$
}

\begin{abstract}
Fingerroot (Boesenbergia pandurata Roxb.) is included to the Zingiberaceae family which has many benefits. Fingerroot crop production has descreaded by $24.46 \%$ from 2014-2016. This is because the provision of plant seeds tends to decrease, this is because nurseries rely solely on the harvest, so propagation can be done through tissue culture. This research aims to determine the most effective sterilization techniques for growth fingerroot explants. This research has conducted at Tissue Culture Laboratory of Horticulture Seedlings and Various Plants Pasir Banteng Sumedang, West Java, from March 2018 to February 2019. The method used is descriptive method. The results

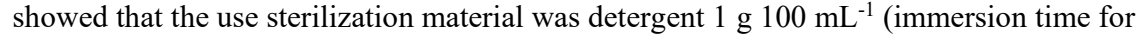
5 minutes), antibacterial solution 3 drops $100 \mathrm{~mL}^{-1}$ (immersion time for 60 minutes), insecticide $11 \mathrm{~g} \mathrm{~L}^{-1}$ (immersion time for 60 minutes), fungicide $10 \mathrm{~g} \mathrm{~L}^{-1}$ (immersion time for 120 minutes), bactericidal $10 \mathrm{~g} \mathrm{~L}^{-1}$ (immersion time 60 for minutes), alcohol $70 \%$ (immersion time for 5 minutes), $\mathrm{HgCl} 0.2 \%$ (immersion time for 7 minutes) and $\mathrm{NaClO}$ (immersion time for 10 minutes) gave the best results with the number of live explants as much as $14.8 \%$.
\end{abstract}

Keyword: fingerroot, shoot, sterilization

\section{Introduction}

Fingerroot is a plant of the Zingiberaceae family which has a distinctive rhizome that grows vertically downward. Besides being used as a cooking spice, fingerroot is also efficacious as a medicine [1]. The demand for fingerroot plants in Indonesia is quite high, in 2008 it reached 9,576 tons / year. This request is to fulfill the needs of herbal medicine carriers, traditional medicine industries (IOT) and kitchen spices. This is because in a rhizome of fingerroot plant containing panduratin $\mathrm{A}$ which is a chalcone derivative which has biological effects, such as anti-inflammatory, analgesic, anticancer and antioxidants [2].

The Central Bureau of Statistics and the Directorate General of Horticulture (2016), stated that production of fingerroot in Indonesia has decreased from 2014-2016 and in the last year has decreased by $24.46 \%$. The cultivation is still conventional is needed many seeds, while the availability of seeds is limited, then in terms of quality of planting material originating from the rhizomes are very susceptible to disease [3]. Tissue culture methods are developed to help 
multiply plants. Tissue culture is a micro propagation or production of plants in large quantities and the time needed is relatively shorter [4].

The initial stage in the tissue culture process is sterilization. Sterilization is the most difficult part in the seed production process throught tissue culture. The proper combine of sterile materials and the immersion time is one of the factors that determine the success of sterilization techniques. The use of sterile material that is too thick and the time is too long can eliminate the source of contaminants but also can ihibit explant growth and even cause death in plant tissue, while the concentration of sterile material that is too low and the immersion time is too short is less effective in killing contaminants such as fungi and bacteria [5]. There are several sterilization chemicals needed for sterilization of explants namely sodium hypochlorite $(\mathrm{NaClO})$, mercury $\left(\mathrm{HgCl}_{2}\right)$, detergent and alcohol [6]. The combination of sterile materials and proper immersion time is one of the factors that determine the success of the sterilization technique. The material used and the sterilization method are different for each plant, so the ingredients and methods are not necessarily successful if applied to different materials, so in tissue culture explant sterilization methods must be tried several times.

\section{Materials And Methods}

\subsection{Time and Place}

This research was conducted from March 2018 to February 2019 at Tissue Cultur Laboratory of Horticulture Seedlings and Various Plants Pasir Banteng Sumedang, West Java.

\subsection{Materials and Tools}

The materials used in this research are buds on fingerroot, sterile material (Table 1), MS media. 
Table 1. The combine of sterile material, concentrate and immersion time

\begin{tabular}{|c|c|c|c|}
\hline Sterilization techniques & Sterile material & Concentrate & Times \\
\hline \multirow{3}{*}{ Sterilization 1} & Alcohol & $70 \%$ & 5 , \\
\hline & $\mathrm{HgCl}_{2}$ & $0,2 \%$ & $7^{\prime}$ \\
\hline & $\mathrm{NaClO}$ & $20 \%$ & $10^{\prime}$ \\
\hline \multirow{4}{*}{ Sterilization 2} & Antibacterial & 3 drops $/ 100 \mathrm{ml}$ & 1 hour \\
\hline & Fungicides & $1 \%$ & 1 hour \\
\hline & $\mathrm{NaClO}$ & $10 \%$ & 20 \\
\hline & Alcohol & $70 \%$ & $30 "$ \\
\hline \multirow{4}{*}{ Sterilization 3} & Detergent & $1 \mathrm{~g} 100 \mathrm{~mL}^{-1}$ & 10, \\
\hline & $\mathrm{HgCl}_{2}$ & $0,2 \%$ & 4 ' \\
\hline & $\mathrm{NaClO}$ & $30 \%$ & $10{ }^{\prime}$ \\
\hline & $\mathrm{NaClO}$ & $20 \%$ & $12^{\prime}$ \\
\hline \multirow{4}{*}{ Sterilization 4} & Alcohol & $70 \%$ & 7 \\
\hline & $\mathrm{HgCl} 2$ & $0,2 \%$ & 5 , \\
\hline & $\mathrm{NaClO}$ & $30 \%$ & 5 \\
\hline & $\mathrm{NaClO}$ & $20 \%$ & $10^{\prime}$ \\
\hline \multirow{8}{*}{ Sterilization 5} & Detergent & $1 \mathrm{~g} 100 \mathrm{~mL}^{-1}$ & 5 \\
\hline & Antibacterial & 3 drops $/ 100 \mathrm{ml}$ & 1 hour \\
\hline & Insecticides & $11 \mathrm{gL}^{-1}$ & 1 hour \\
\hline & Fungicides & $10 \mathrm{gL}^{-1}$ & 2 hour \\
\hline & Bactericides & $10 \mathrm{gL}^{-1}$ & 1 hour \\
\hline & Alcohol & $70 \%$ & 5 \\
\hline & $\mathrm{HgCl}_{2}$ & $0,2 \%$ & 7 , \\
\hline & $\mathrm{NaClO}$ & $20 \%$ & 10 ' \\
\hline
\end{tabular}

The tools used in this research are petri dish, hand sprayer, filter, beaker glass, autoclave, scales, $\mathrm{pH}$ meter, spatula, magnetic stirrer, stove, jam bottles, tweezers, culture shelves, bunsen, laminar air flow (LAF), AC, plastic wrap, label, camera and stationery.

\subsection{Research Design}

Research method are used in this research is descriptive which consist of five experiments.

The results analyzed with descriptive method, by calculating the percentage of live explants, die explants and percentage of contamination.

\section{Results And Discussion}

The use of absolute sterilization materials in plant cultivation in vitro. Propagation without used sterile materials that cause high contamination. 
Table 2. The observation results of the effect of various sterilization techniques to the growth of fingerroot explants.

\begin{tabular}{cccccc}
\hline Sterilization & Live Explants & Die Explants & \multicolumn{3}{c}{ Contamination (\%) } \\
techniques & $\mathbf{( \% )}$ & $\mathbf{( \% )}$ & Fungi & Bacteria & $\begin{array}{c}\text { Fungi \& } \\
\text { bacteria }\end{array}$ \\
\hline Sterilization 1 & 0 & 100 & 77,7 & 7,4 & 14,8 \\
Sterilization 2 & 0 & 100 & 88,8 & 3,7 & 7,4 \\
Sterilization 3 & 0 & 100 & 70,4 & 22,2 & 7,4 \\
Sterilization 4 & 0 & 100 & 7,4 & 22,2 & 3,7 \\
Sterilization 5 & 14,8 & 85,2 & 29,6 & 18,5 & 11,1 \\
\hline
\end{tabular}

That the results analyzed, contamination for five sterilization techniques are external contamination because to appear on 3-5 days after initiation/planting (Figure 1). All kinds of contamination for explants among others fungi are characterized by hyphae from the surface of outside body's explant, then to distributed until the surface of media. The kind of fungi which growth is Muchor, are characterized by hyphae the color is white to dark grey.

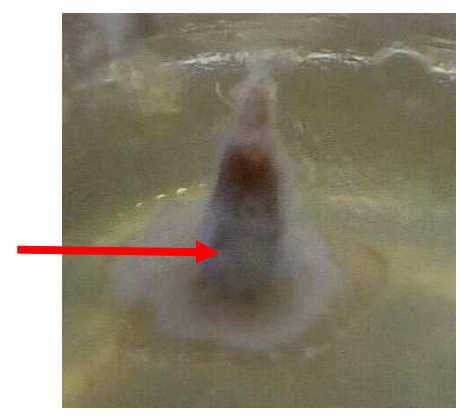

Figure 1. Contamination by fungi, the kind is Muchor

The source of contamination which caused by bacteria to show characterized by mucus the color is white to yellow on the surface of media (Figure 2). 


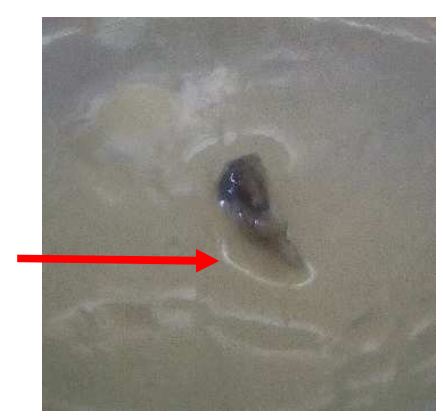

Figure 2. Contamination by bacteria

Contamination which caused by fungi and bacteria are unite from the two, this contamination is most danger because faster to distributed (Figure 3).

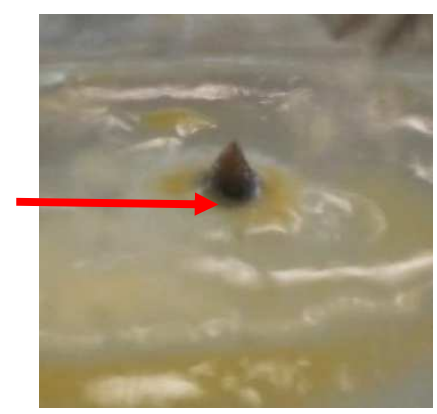

Figure 3. Contamination by fungi and bacteria

That the results, sterilization 5 is the techniques which most effective from the others, there are $14.8 \%$ live explant (Figure 4 ) are succeed to growth and healthy, but the percentage of die explant is quite high is $85.2 \%$. This is because the use of sterile material, concentrate and the immersion time is excessive, so proved physiological effect to explant growth and cause death to the tissue. 


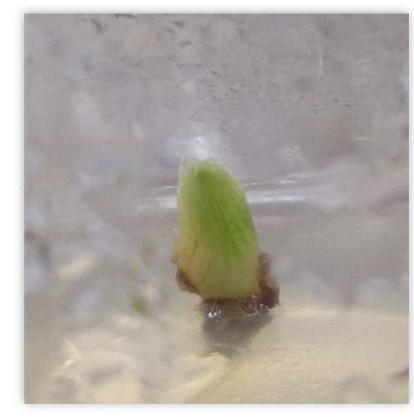

Figure 4. Live explant

Detergent used to clean the explant and clear the microorganism of the explant. Cleaning is too long can damage the tissue of explant, so used the low concentrate and immersion time is short. The use of insecticides is to clear the insect of the explant. The use of bactericides is to clear bacteria of explant, but that the results contamination by bacteria is quite high, this is because sterilization techniques by bactericides not yet effective. The use of fungicides is intended to kill microorganism that cause fungal contamination. However, based on observations, the highest of contamination by fungi occurs because the technique of using of fungicides has not been effective in killing microorganism that cause fungi. The use of $\mathrm{HgCl}_{2}$ has been done to overcome contamination originating from the field, because it is very toxic and can kill microorganism that cause contamination. $\mathrm{NaClO}$ solution is able to sterilize plant tissue and increase the number of plant shoots. The use of $70 \%$ alcohol is effective in sterilizing plants with high success rates, this occurs when the concentration and length of immersion are suitable for sterilized explants. The use of $\mathrm{NaClO}$ and $70 \%$ alcohol with a high concentration can cause browning and reduce the regeneration ability of fingerroot explants.

\section{Conclusion}

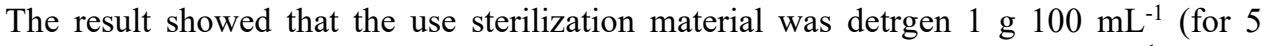
minutes), antibacterial solution 3 drops $100 \mathrm{~mL}-1$ (for 60 minutes), insecticide $11 \mathrm{~g} \mathrm{~L}^{-1}$ (for 60 minutes), fungicide $10 \mathrm{~g} \mathrm{~L}^{-1}$ (for 120 minutes), bactericidal $10 \mathrm{~g} \mathrm{~L}^{-1}$ (60 for minutes), alcohol $70 \%$ (for 5 minutes), $\mathrm{HgCl}_{2}$ 0.2\% (for 7 minutes) and $\mathrm{NaClO}$ (for 10 minutes) gave the best results with the number of live explants as much as $14.8 \%$.

Modification of sterilization techniques on fingerroot explants need to be carried out until more precise and effective sterilization techniques are found so that they can produce more live explants and healthier explants.

\section{References}

[1] W. Yulianti, Indrian, N. Juniati, T. P. Raharjo, B. N. Utami, and F. Kharisma, "Pengembangan Tanaman Obat Temu Kunci," 2016.

[2S] D. Kusbiantoro and Y. Purwaningrum, "Pemanfaatan kandungan metabolit sekunder pada tanaman kunyit dalam medukung peningkatan pendapatan masyarakat," 
Kultivasi, vol. 17, no. 1, pp. 544-549, 2018.

[3] D. L. Sastra and Neliyati, "Pengaruh BAP terhadap Pertumbuhan Jahe Emprit (Zingiber officinale Rosc. Var. Amarun)," J. Agron., vol. 8, no. 2, pp. 81-85, 2003.

[4] A. D. Susila, Panduan Budidaya Tanaman Sayuran. Bogor: IPB Press, 2006.

[5] H. F. Rismayani, "Pengaruh Pemberian Chlorox $(\mathrm{NaOCl})$ pada Sterilisasi Permukaan untuk Perkembangan Bibit Aglaonema (Donna Carmen) secara In Vitro," in Prosiding Seminar Ilmiah dan Pertemuan Tahunan PEI dan PF XX Komisariat Daerah Sulawesi Selatan, 2010.

[6] A. Shofiyani and D. H. Oetami, "Pengaruh Sterilan dan Waktu Perendaman pada Eksplan Daun Kencur (Kaemferia galangal L.) untuk Meningkatkan Keberhasilan Kultur Kalus,” J. Agritech, vol. 12, no. 1, pp. 11-29, 2010. 